Association for Information Systems

AIS Electronic Library (AISeL)

Wirtschaftsinformatik Proceedings 2005

Wirtschaftsinformatik

February 2005

\title{
Strategic Channel Alignment - Perspectives on the Combination of Physical and Virtual Distribution Channels
}

\author{
Claas Müller-Lankenau \\ University of Muenster, Germany \\ Kai Wehmeyer \\ University of Muenster, Germany \\ Stefan Klein \\ University College Dublin, Ireland
}

Follow this and additional works at: http://aisel.aisnet.org/wi2005

\section{Recommended Citation}

Müller-Lankenau, Claas; Wehmeyer, Kai; and Klein, Stefan, "Strategic Channel Alignment - Perspectives on the Combination of Physical and Virtual Distribution Channels" (2005). Wirtschaftsinformatik Proceedings 2005. 10.

http://aisel.aisnet.org/wi2005/10

This material is brought to you by the Wirtschaftsinformatik at AIS Electronic Library (AISeL). It has been accepted for inclusion in Wirtschaftsinformatik Proceedings 2005 by an authorized administrator of AIS Electronic Library (AISeL). For more information, please contact elibrary@aisnet.org. 
In: Ferstl, Otto K, u.a. (Hg) 2005. Wirtschaftsinformatik 2005: eEconomy, eGovernment, eSociety; 7. Internationale Tagung Wirtschaftsinformatik 2005. Heidelberg: Physica-Verlag

ISBN: 3-7908-1574-8

(C) Physica-Verlag Heidelberg 2005 


\title{
Strategic Channel Alignment - Perspectives on the Combination of Physical and Virtual Distribution Channels
}

\author{
Claas Müller-Lankenau, Kai Wehmeyer \\ University of Muenster, Germany
}

\section{Stefan Klein}

University College Dublin, Ireland

\begin{abstract}
Extensive integration of online and offline channels is often considered the preferable strategy for multi channel retailing. However, empirical findings contradict this assumption and show that retailers choose divergent multi channel strategies. In this paper, we present a model of strategic channel alignment and define four alignment perspectives that can help to reconstruct and interpret decisions on multi channel strategies as an alignment of general marketing strategy and online strategy. An application of the model to the cases of four prominent and successful players from the grocery retailing industry shows that although the companies pursue fundamentally different multi channel strategies, they are all examples of successful alignment and mature multi channel strategies. ${ }^{1}$
\end{abstract}

Keywords: Multi channel management, strategic alignment, e-commerce, grocery retailing

\section{Introduction}

Discussions and perspectives on the success of Internet retailing have gone through several phases. In the early days of the New Economy, the Internet, as a retailing channel, was widely considered to be superior to store-based retailing channels. Yet, on the opposite end, some considered the New Economy boom as a mere hype phenomenon without lasting impact on the economy. It was expected

This publication is based on work done within the research cluster "Internet Economy" at the University of Münster. The authors wish to thank the German Federal Ministry of Education and Research (BMBF) for financial support (grant number 08 NM 065 A). 
that, as soon as the hype was over, the Internet would no longer play an important role.

After the New Economy bubble had burst and the dust had settled, a new perspective, that had already been proclaimed in early phases of the Internet boom [StK199], gained popularity: the simultaneous use or integration of online and offline channels by retailers, also termed click \& mortar or multi channel (in the sense of combining physical and virtual channels) retailing. The Internet, and to an increasing extent mobile technologies, continuously inspire visions of completely integrated online and offline channels that support customer channel switching in any transaction phase [RhSh02; $\left.\mathrm{Ste}^{+} 02\right]$.

Expectations regarding the profitability of extensive channel integration are high. Consultancies for example claim that multi channel customers are more loyal and two to four times more profitable than single channel customers [OC\&C02]. Empirical evidence however shows that a great majority of retailers do not or only to a very limited degree integrate their physical and virtual channels. Often named measures of channel integration such as in-store pick-up or in-store return of goods ordered online have only been implemented by a fraction of retailers. Even basic online purchasing functionality is only offered by a low number of retailers [Stei04].

Based on these contradictory findings, we argue that there is no single best strategy for multi channel retailing, such as a far reaching integration of channels. Rather, it appears that retailers choose fundamentally different multi channel strategies. Even within a single industry, some retailers actually choose to extensively integrate channels, while others implement strategies where one channel dominates the other [Mül $\left.{ }^{+} 04\right]$.

To reconstruct and analyze retailers' choices of multi channel strategies, we adapt the concept of strategic alignment [HeVe93] to the context of multi channel strategies. We interpret the choice of multi channel strategies as an alignment of general marketing and online strategies. In contrast to perspectives proclaiming that a higher degree of integration is per se the more beneficial strategy, this perspective leads to a more differentiated understanding of the appropriateness of retailers' multi channel strategies. We demonstrate this by using the case studies of grocery retailers with mature business models and marketing strategies that play prominent roles within their respective markets.

In chapter 2, we briefly review distinct multi channel retailing strategies to illustrate the strategic diversity in multi channel retailing. Chapter 3 introduces the original strategic alignment model. Subsequently, we present the derived model of strategic channel alignment and associated alignment perspectives which we apply to the four cases from grocery retailing. Limitations of research are discussed in chapter four, leading to the concluding remarks made in the final chapter. 


\section{Diversity in Multi Channel Strategies}

With the ongoing diffusion of Internet technology, traditional retailers face the question whether or not they should set up an internet presence, which functionality a Web site should offer and in how far this Web presence should be integrated with traditional retailing activities.

Based on single success stories, it is often claimed that extensive integration of offline and online channels is highly profitable [OC\&C02]. Furthermore, it is assumed that channel integration is a generally beneficial strategy for retailing [Görs03] and customer relationship management.

In reality however, a majority of retailers hardly integrates physical and virtual channels [Stei04]. It appears that extensive channel integration is not the dominant multi channel strategy, but that retailers choose diverse strategies when combining physical and virtual channels. The following examples illustrate the scope and diversity of chosen strategies [Mül $\left.{ }^{+} 04\right]$.

\section{Offline-dominated strategy}

In an offline-dominated strategy, the online channel plays a supporting role and is mainly used to increase allocation efficiency of the offline channel. Content of the Web site is often limited to information about in-store offerings and store locations, limited additional services such as after sales information might be offered. Possible motivations for pursuing this strategy are: a sophisticated distribution system optimized for providing goods to a network of shops, strategic differentiation by means of in-store customer consultative services which cannot be offered on the Web, or contractual limitations.

\section{Online-dominated strategy}

In online-dominated strategies, the offline channel is configured to guide customers to a corporate Web site or similar online offerings. Communication and promotion activities in the offline realm and possibly incentives such as lower prices or a wider range of products offered online aim to strengthen the online channel. This strategy is typically used to bypass intermediaries or to shift sales volume from a high cost offline channel to the cheaper online channel (which is often the case for digitizable goods). In analogy to offline-dominated strategies, online-only retailers can also try to get access to offline channel infrastructure in order to increase their online profitability or sales volume.

\section{Isolation strategy}

An isolation strategy is pursued when online and offline channels are managed as separate or independent entities, possibly operating under different brand names. Neither communication activities nor incentives or explicit links support or en- 
courage customers to switch between channels. Possible factors supporting a choice of this strategy are the avoidance of channel conflict, targeting different customer groups with e. g. channel-specific pricing schemes or different geographical regions targeted by online and offline channels.

\section{Integration strategy}

In integration strategies, the service portfolios respectively product offerings in both online and offline channels are mainly restricted by technology rather than by strategic decisions favoring one specific channel. The channels are seen as complementary components of a multi channel system that aim to provide a high level of convenience to customers, e. g. through supporting channel hopping in and between transaction phases. This form of differentiation strategy might help to charge premium prices, but also incurs extra costs.

In light of this diversity of multi channel strategies, we argue that a range of interdependent company- and industry-specific factors have a major influence on the development of a company's multi channel strategy. Together, these factors form a complex decision space, within which consistent multi channel strategies have to be formulated. We use a modified version of the strategic alignment model that encompasses major factors in the areas of general marketing and online activities in order to identify basic patterns of multi channel strategizing.

\section{Strategic Channel Alignment}

The theme of aligning online and offline strategies and indeed translating strategies into tangible measures occurred time and again. The classification and comparison of multi channel strategies remains challenging due to a strong variance in internal and external factors which determine the degree and nature of channel integration. Therefore, we propose to use the strategic alignment model, which has been developed by Henderson and Venkatraman [HeVe93] and led to further work by Luftman [Luft96b; Luft03b] and Papp [Papp01b] as a starting point. We adapt the original model to facilitate the understanding and classification of offlineonline channel alignment (Figure 2).

\subsection{The Strategic Alignment Model}

\subsubsection{Description of the Model}

Henderson and Venkatraman [HeVe93] developed the strategic alignment model to describe the strategic choices facing managers when aligning IT and business. It is based on the distinction between business and information technology as sepa- 
rate areas of management concern. In addition, it distinguishes an external view and an internal view on the former (Figure 1).

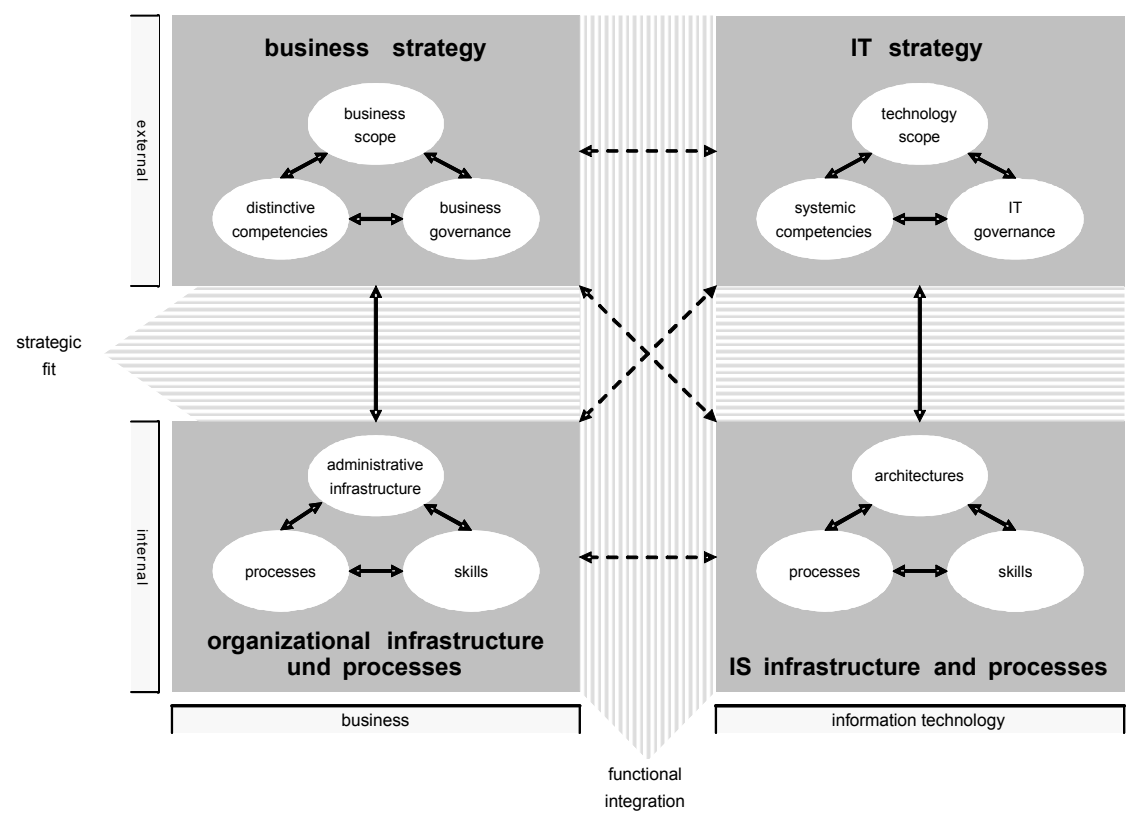

Figure 1: Strategic Alignment Model (Henderson/Venkatraman 1993)

The external view focuses the business arena of the competing firm and encompasses the domains "business strategy" and "IT strategy" [HeVe93]. The internal view looks at the institutional, organizational, and infrastructural system which is installed to steer and enable a company's core business processes. It includes the model's remaining two domains "organizational infrastructure and processes" and "IS infrastructure and processes". Each of the four domains has been further specified by a subset of three components [Luft96c].

A basic assumption of the model is that the management's ability to achieve a strategic fit (vertical relationship in Figure 1) between the external and internal domains is linked to overall business success [Hen $\left.{ }^{+} 96\right]$. Furthermore, the construct of fit is recognized to be dynamic and related to industry and market changes by their implications on the continuing process of strategic and organizational development [HeVe93]. Since Henderson and Venkatraman differentiate between business and IT as separate domains, they additionally postulate the need for horizontal inter-domain coordination - here called functional integration. It describes the dictum to align choices made in the IT and the business domain on the strategic as well as on the operational level [Nels01]. Eventually, the fact that both domains are equally considered to have the power to threaten or enhance each other and 
have a major impact on overall profitability has profoundly changed strategic management's perspective of the IT domain.

\subsubsection{Alignment Perspectives}

The concept of strategic alignment calls for a balance among all four domains of the model. A bivariate fit between each of the domains appears difficult to achieve because of potential internal inconsistencies and conflicts [HeVe93]. Therefore, so called alignment perspectives have been developed which describe certain "management styles" in linking business and IT strategies and operations. It is proposed that each perspective comprises at least three domains $\left[\mathrm{Hen}^{+} 96\right]$ and a characteristic direction or "path of alignment".

\begin{tabular}{|c|c|c|}
\hline Anchor Domain & Pivot Domain & Impact Domain \\
\hline $\begin{array}{l}\text { The anchor domain is the cata- } \\
\text { lyst or the enabler of the per- } \\
\text { spective. At times it is the driver } \\
\text { of change. It is the starting } \\
\text { point and the domain that is } \\
\text { usually the most stable. Often- } \\
\text { times, it is the area that has } \\
\text { most recently been addressed. } \\
\text { It is in a strong position to drive } \\
\text { the planning process. }\end{array}$ & $\begin{array}{l}\text { The pivot domain is usually the } \\
\text { area that has the problem or } \\
\text { the opportunity that is being } \\
\text { addressed. The anchor domain } \\
\text { is the catalyst that helps to } \\
\text { address the pivot. }\end{array}$ & $\begin{array}{l}\text { The impact domain is the area } \\
\text { that is being affected by the } \\
\text { change to the pivot. There is a } \\
\text { need to ensure an understand- } \\
\text { ing of the implications of those } \\
\text { changes to the impact domain. }\end{array}$ \\
\hline
\end{tabular}

Table 1: Anchor, Pivot and Impact Domain (Luftman 1996a)

The management of alignment processes always includes challenges of strategic fit as well as functional integration achievement. Luftman postulates a slightly different view on the alignment perspectives when he elaborates on the specific roles which each of the three domains of one perspective hold. Of the three domains the "anchor domain" denotes the first, "pivot domain" the second and "impact domain" the third quadrant [Luft96b; Papp01b]. Table 1 presents the descriptions of the three following Luftman [Luft96a].

\subsubsection{Previous Research on Strategic Alignment}

There has been extensive research on further applications of the strategic alignment model [Luft96b; Luft03b]. Papp and Luftman [PaLu95] identified additional alignment perspectives and delivered empirical evidence for their existence by associating them with real-world business cases. Furthermore, perspectives have been combined to so-called "fusions" which describe more complex processes with parallel alignment activities [Papp01a]. The concept of strategic alignment has been applied to a multitude of specific business arenas and functions. These include E-Commerce [Baue01; Naka01] or networks [Bar190]. 


\subsection{A Model of Strategic Channel Alignment}

The strategic alignment model can be adapted to assess specific functional application domains (e. g. marketing) of IT [Luft96c]. We follow Luftman's suggestion to apply the model to a specific problem when introducing a model of strategic channel alignment, which focuses on the coordination of traditional marketing strategy and infrastructure and corresponding online strategy and infrastructure. An application of the alignment model to the coordination of multi channel activities requires a modification of the model's elements and a refinement of its scope.

\subsubsection{Description of the Model of Strategic Channel Alignment}

The alignment between marketing and online strategy differs from the original ideas of Henderson and Venkatraman to focus on the general business and the IT side of organisational activities. The modified model of strategic channel alignment (Figure 2) depicts the major differences.

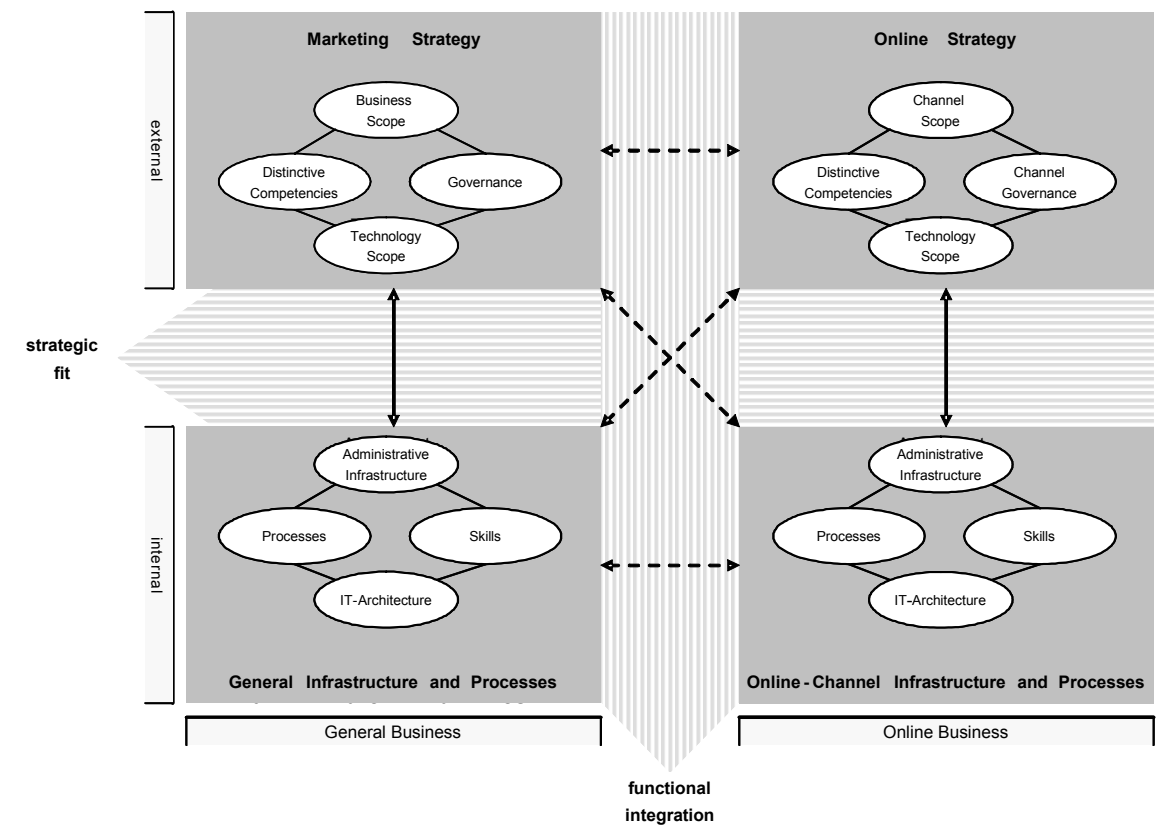

Figure 2: Model of Strategic Channel Alignment

Marketing and online strategy are considered to be broad concepts that each include reflections on the strategic use of IT, however, concentrating on the assigned channels. We here understand marketing strategy to be the planning of all activities seized by one company that are customer oriented and part of the traditional "brick-and-mortar" business. Respectively, online strategy is also a strategic mar- 
keting plan, but deals exclusively with customer oriented activities in and over the electronic online channel. Furthermore, marketing strategy is very closely linked to the traditional business scope, whereas online strategy can potentially be more autonomous. It is not necessarily strongly integrated with the general business scope, but can develop a more independent "channel scope" of activities. In the external domain the challenging management task is the functional integration of marketing and online strategy.

Consequently, the internal domain does not include Henderson and Venkatraman's business/IT-duality, but a differentiation between general, "brick-andmortar" and online channel infrastructure and processes. Both domains include IT architecture and the already known subdomains of the original strategic alignment model. A functional integration in the internal domain would therefore be not only a task of coordinating processes, administration and human factors, but also of aligning the IT-architecture and information systems. It is not an imperative that the level of functional integration between online and general business infrastructure and processes is high even when online and offline activities are closely linked regarding managerial governance.

Eventually, the model of strategic channel alignment offers a new perspective on the coordination of online and offline activities of a company or a network of partners. The achievement of functional integration and strategic fit is not trivial but challenging. We break with the original model's dictum to strive for a maximum of alignment and integration and postulate a more flexible application of our model. Constellations of online/offline channel alignment should be examined with regard of the numerous constraints that emerge e. g. from the core strategy of the traditional business (partner) or the limited financial, technical or human ressources. The model will be used to assess and explain different options in combining the considered channels.

\subsubsection{Alignment Perspectives: Four Cases from the Grocery Retail Industry}

Based on the approach of Luftman [Luft96a], we have developed four different alignment perspectives (see section 3.1.2). We illustrate each of the four perspectives by a case from the grocery retailing industry. The case companies are all prominent players within their markets with mature business models and marketing strategies. Hence we assume that their multi channel strategy is beyond a stage of experimentation. The perspectives as depicted in Figure 3 are named similarly to the original four perspectives [HeVe93]. 


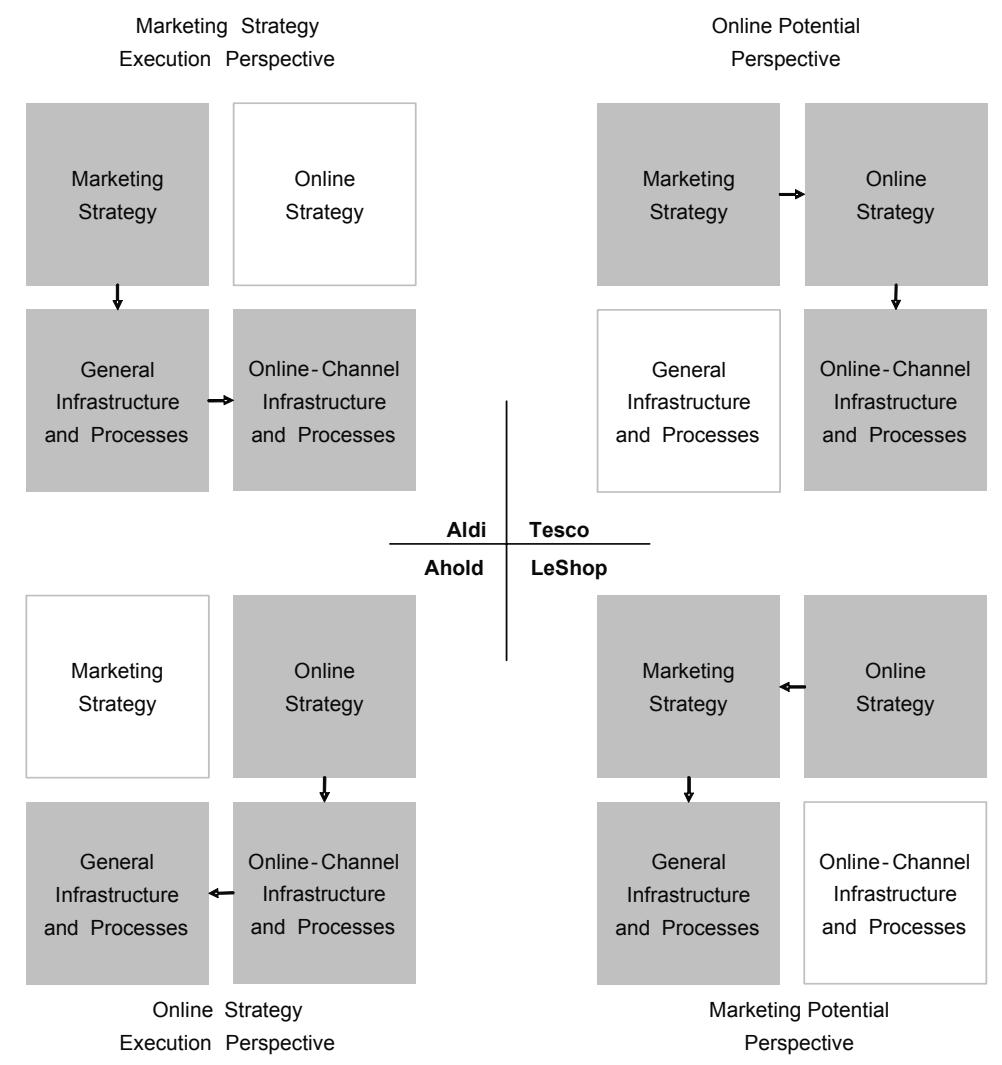

Figure 3: Alignment Perspectives

The different perspectives including the considered paths of alignment and the domains involved are explained and illustrated below.

\section{Marketing strategy execution}

The marketing strategy execution perspective (see Figure 3) considers the (brick $\&$ mortar) marketing strategy to be the driver for the design of general infrastructure and processes and secondly determines the configuration of the online channel's infrastructure and processes as well. Henderson et al. see their version of this perspective as a mirror of the classic hierarchical view of strategic management $\left[\mathrm{Hen}^{+} 96\right]$. A marketing strategy, often with a strong focus on the distinctive competencies and a clearly described business scope, strictly regulates the use of the online channel. A sophisticated online strategy is not likely to exist. Opportunities of the online channel are only exploited to a limited extent which is predefined by the general marketing strategy. 


\section{Case ALDI}

ALDI operates more than 5,000 stores in 13 different countries on three continents. It has a widespread network of stores all over Germany, its core market. Consistently and vigorously pursuing a discount strategy, ALDI's focuses on providing a limited assortment of private label products at low prices and good quality. In addition to a core range of standard groceries and non-food household items, a "Special Purchases" line of goods that changes once or twice a week is offered (overall below 1000 items). ALDI's business model has proven to be highly successful: by sales ALDI is on the rank 18 of the world's largest retailers.

\section{Description of multi channel activities}

ALDI's Web sites (http://www.aldi.com, http://www.aldi.de|fr|nl|...) have the following functionalities: next to a store locator, general information on the company and new products in the basic assortment, the main focus of the Web sites is to present information on the Special Purchases. Placing orders online is not possible. Community building measures do not exist, as the only online marketing tool is a weekly e-mail newsletter that is offered in Germany. Thus, the Internet is mainly used as promotion channel. It supports the information phase aiming to increase allocation efficiency of the traditional distribution channel. The Internet presence reflects only a small subset of the offline assortment and is scarce in content. It has no significant influence on processes or transactions in the physical outlets and is not actively promoted in ALDI's marketing communications.

\section{Explanation of the domains involved}

ALDI's very special case is an example for Marketing Strategy Execution. The path of alignment wich can be assumed for ALDI is briefly described in Table 2.

\begin{tabular}{|c|c|c|c|}
\hline ALDI & Anchor Domain & Pivot Domain & Impact Domain \\
\hline \multirow{2}{*}{$\begin{array}{l}\text { Marketing } \\
\text { Strategy } \\
\text { Execution } \\
\text { Perspective }\end{array}$} & Marketing Strategy & $\begin{array}{l}\text { General Infrastructure } \\
\text { and Processes }\end{array}$ & $\begin{array}{c}\text { Online-Channel Infra- } \\
\text { structure and Proc- } \\
\text { esses }\end{array}$ \\
\hline & $\begin{array}{l}\text { ALDI follows a no } \\
\text { frills, cost leader mar- } \\
\text { keting strategy ad- } \\
\text { dressing anonymous } \\
\text { customers. Hardly } \\
\text { any online services } \\
\text { are offered. The low- } \\
\text { cost dictum deter- } \\
\text { mines almost all ac- } \\
\text { tivities. }\end{array}$ & $\begin{array}{l}\text { ALDI's infrastructural fo- } \\
\text { cus is on the retail out- } \\
\text { lets. The physical chan- } \\
\text { nel design is highly } \\
\text { streamlined and follows } \\
\text { the strict marketing } \\
\text { strategy. Communication } \\
\text { measures are scarce, } \\
\text { but effective to put } \\
\text { across the weekly spe- } \\
\text { cial purchases }\end{array}$ & $\begin{array}{l}\text { As a result of market- } \\
\text { ing strategy execution, } \\
\text { the online infrastructure } \\
\text { and functionalities of } \\
\text { ALDI is very limited. } \\
\text { The online channel is } \\
\text { mainly used as suppor- } \\
\text { tive communication } \\
\text { tool. }\end{array}$ \\
\hline
\end{tabular}

Table 2: Marketing Strategy Execution - the Case of ALDI 


\section{Online strategy execution perspective}

The online strategy execution perspective (see Figure 3) claims that online strategy is the anchor and driver of change in online channel infrastructure and processes. This presumes that an online strategy is formulated and passed for implementation. With the aim to achieve a strategic fit between online strategy and online channel infrastructure and processes, management tries to create the desired fundament of online activities. So far the classic hierarchical view of strategic management applies again - however in the subdomain of online strategy. Yet, the rest of the alignment path brings about the impact on the traditional brick \& mortar business. If channels are not completely autonomous, the online channel activities will to some extent influence the way the company operates in other (physical) channels. This can either be made visible to the customers by communication measures or not. Even changes in internal operations and structures apply here.

\section{Case AHOLD}

AHOLD is the largest food retailer in The Netherlands and with its operations on four continents AHOLD has become the $3^{\text {rd }}$ biggest global retailer. In 2002 it achieved sales of almost USD 60,000 Mio [Ahol04a; n.a.03] and operated 5,606 stores, $60 \%$ of them supermarkets, through its consolidated subsidiaries. The U.S. based activities include six traditional retail companies with regional foci in eastern and southern states. The integration and consolidation of AHOLD USA is a major part of the recently announced strategy plan called 'Road to Recovery' [Ahol04a].

\section{Description of multi channel activities}

AHOLD USA heads six traditional retail companies and Peapod, an Internet supermarket. Peapod is an independent company with its own brand and Web presence (http://www.peapod.com). AHOLD gained control over Peapod in June 2000 and made it a wholly owned subsidiary by July 2001. Peapod's sales in 2002 reached USD 117 Mio and were already up to USD 107 Mio by the third quarter of 2003 [Ahol04b]. The company provides online grocery shopping and delivery services in five metropolitan areas in the US [Peap04]. In the Chicago region, Peapod operates its own infrastructure, including warehouses and distribution centers. In other regions, Peapod cooperates with AHOLD's Stop \& Shop or Giant Food markets. It thus pursues a hybrid model with stand-alone distribution centers and AHOLD's chain store infrastructure. Therefore, Peapod's costs can be kept at a lower level while expanding their geographical reach. Stop \& Shop and Giant both link to Peapod's online shop on their Web sites. AHOLD USA uses Peapod's brand and expertise in online retailing to extend their traditional business into the online channel and therefore prevents its regional chains from operating their own online retailing activities. 


\section{Explanation of the domains involved}

AHOLD's case depicts an example of the online strategy execution perspective. Linkages between online and traditional activities are most likely only subject to alignment activities in the internal domains of infrastructure and processes. Functional integration between online and traditional marketing strategy is low. The assumed path of alignment is described in Table 3 .

\begin{tabular}{|c|c|c|c|}
\hline AHOLD & Anchor Domain & Pivot Domain & Impact Domain \\
\hline \multirow{2}{*}{$\begin{array}{l}\text { Online } \\
\text { Strategy } \\
\text { Execution } \\
\text { Perspec- } \\
\text { tive }\end{array}$} & Online Strategy & $\begin{array}{c}\text { Online-Channel Infra- } \\
\text { structure and Proc- } \\
\text { esses }\end{array}$ & $\begin{array}{c}\text { General Infrastructure } \\
\text { and Processes }\end{array}$ \\
\hline & $\begin{array}{l}\text { AHOLD USA follows an } \\
\text { online strategy which } \\
\text { does not affect tradi- } \\
\text { tional marketing activi- } \\
\text { ties of its retail chains. } \\
\text { The strategic decision } \\
\text { to enter the online gro- } \\
\text { cery retailing market is } \\
\text { realized by the acquisi- } \\
\text { tion of Peapod, an es- } \\
\text { tablished player. }\end{array}$ & $\begin{array}{l}\text { AHOLD gained instant } \\
\text { access to a mature and } \\
\text { comprehensive online } \\
\text { infrastructure by ac- } \\
\text { quiring Peapod. } \\
\text { Changes in this domain } \\
\text { occur in terms of an } \\
\text { initial creation. }\end{array}$ & $\begin{array}{l}\text { The general, physical } \\
\text { infrastructure was in- } \\
\text { fluenced by linking } \\
\text { Peapod to the existing } \\
\text { non-transactional } \\
\text { online operations of the } \\
\text { retail chains. Logistics } \\
\text { and facilities are } \\
\text { shared amongst Pea- } \\
\text { pod, Giant, and Stop \& } \\
\text { Shop. }\end{array}$ \\
\hline
\end{tabular}

Table 3: Online Strategy Execution - the Case of Ahold

\section{Online potential perspective}

The online potential perspective (see Figure 3) involves developing an online strategy in response to a general marketing strategy. The formulation of the online strategy defines the required online channel infrastructure and processes. Key characteristic of this perspective is the sophisticated marketing strategy that explicitly defines requirements for its extension into the online channel. Online strategy is closely linked and a fully integrated subset of general marketing strategy. To the customer this is oftentimes visible by a complex service portfolio that spans across several marketing channels. Marketing strategy seeks to exploit the online channels potential for leveraging customer service, CRM activities, etc. Online channel infrastructure and processes are subsequently impacted by the implementation of the online strategy. The focus is on the functional integration of the external domains, aligning marketing and online scope and competencies on a strategic level. Strategic fit is primarily aimed at on the online business side. However, a succeeding functional integration of online and general infrastructure and processes appears likely in highly integrated multi channel systems. 
Case TESCO

TESCO is UK's leading grocery chain and was ranked $8^{\text {th }}$ by sales of the world largest retailers in 2002 [n.a.03]. In early 2003, TESCO operated 2,291 stores in 10 different countries and employed 296,000 people [Madd03]. After struggling in a severe price competition in its British home market in the early 1990s, TESCO was successful in relying on sales of non-food items and international expansion. The strategy was redefined to a customer centric approach with the core purpose of creating value for their customers to earn their lifetime loyalty [Tesc03]. TESCO's loyalty scheme "Clubcard" has become an inter-industry benchmark for customer profiling and CRM [McKe03].

\section{Description of multi channel activities}

TESCO launched its online channel Tesco Direct in 1996. Until 2000 the offer was limited to groceries and only run on a regional basis. Since then, TESCO moved beyond online grocery retailing and offered a wide variety of products on their Web site http://www.tesco.com, which was simultaneously installed as brand name for TESCO's online activities. Shortly after, TESCO was already considered the world's largest and most profitable Internet grocer [Seyb01]. What differentiates tesco.com from other online retailers is the fact that it does not operate its own warehouses, but enables the customer to buy online from their familiar local TESCO store. Each store's pricing and inventory system is linked directly to tesco.com, so that customers can select from the line of goods with prices they are used to. The orders are composed in the local stores and delivered by tesco.com vans in a customer defined two-hour delivery window [Seyb01]. Online customers are charged GBP 5 for delivery which indicates the fact that their price-sensitivity is rather low compared to the average shopper. The channel integration at TESCO is complemented by the Clubcard loyalty scheme. Customer shopping behavior can be recorded in both channels and is used to optimize the personalized marketing activities. 


\begin{tabular}{|c|c|c|c|}
\hline Tesco & Anchor Domain & Pivot Domain & Impact Domain \\
\hline \multirow{2}{*}{$\begin{array}{l}\text { Online } \\
\text { Potential } \\
\text { Perspec- } \\
\text { tive }\end{array}$} & Marketing Strategy & Online Strategy & $\begin{array}{l}\text { Online-Channel Infra- } \\
\text { structure and Proc- } \\
\text { esses }\end{array}$ \\
\hline & $\begin{array}{l}\text { TESCo's marketing } \\
\text { strategy is customer- } \\
\text { centric. Creating value } \\
\text { for the customer and } \\
\text { gaining his loyalty is } \\
\text { stressed. Extensive } \\
\text { customer data collec- } \\
\text { tion is a means. All } \\
\text { channels operate } \\
\text { jointly and complemen- } \\
\text { tary. }\end{array}$ & $\begin{array}{l}\text { TESCO pursues an } \\
\text { online strategy that } \\
\text { aims at delivering a } \\
\text { plentitude of services } \\
\text { and possibilities to the } \\
\text { customer. Strategic } \\
\text { customer data informa- } \\
\text { tion management and } \\
\text { integration is highly } \\
\text { developed and part of } \\
\text { the strategic compe- } \\
\text { tencies. }\end{array}$ & $\begin{array}{l}\text { The online strategy led } \\
\text { to a highly complex } \\
\text { infrastructure and a } \\
\text { multitude of operations } \\
\text { thereon. System inte- } \\
\text { gration is high. Trans- } \\
\text { action and communica- } \\
\text { tion are offered and } \\
\text { synchronized with off- } \\
\text { line activities. }\end{array}$ \\
\hline
\end{tabular}

Table 4: Online Potential Perspective - the Case of TESCO

\section{Explanation of the domains involved}

TESCO has a very strong marketing strategy. It focuses on building customer loyalty by delivering highly personalized and relevant services additional to selling groceries. TESCO integrates physical and online channels to a harmonized system that serves customers on several touch points. Online strategy complements the company-wide marketing strategy. Thus, we see the TESCO case as an example of the online potential perspective. Table 4 gives a brief description.

\section{Marketing potential perspective}

The marketing potential perspective (see Figure 3) deals with the exploitation of online channel capabilities to impact the general strategic orientation of a company. New distinctive competencies might be created and new forms of business relationships and governance structures can emerge. These changes in traditional structure and strategy then lead to a redesign of general infrastructure and processes. Companies which show this path of alignment typically have flexible structures and a commitment to change and learning, as the evolution of the online possibilities are assigned the power to influence the general way business is done. Online strategy is not only a part of marketing strategy but is anchor and driver of change. Innovations in online strategy even have a mediated impact on general (physical) infrastructure and processes in marketing.

\section{Case LESHOP}

Founded in 1997, LESHOP was Switzerland's first online supermarket offering home delivery all over the country. After a promising take-off, it was close to being shut down in December 2002 when majority stock holder Bon appétit Group 
decided to disinvest [LeSh04]. However, LESHOP's management was able to find a group of private investors and enthusiastic clients - ShoppingNet Holding SA and succeeded to continue all activities [Bon 03]. LESHOP's turnover is growing continually and reached CHF 14.7 Mio in 2003. It claims to have a client base of 16,000 regular customers at present [LeSh04].

\section{Description of multi channel activities}

Recent developments make LESHOP an interesting case for multi channel issues. In September 2003 it announced a strategic alliance with Migros, a large Swiss group of cooperatives ranked $47^{\text {th }}$ by sales in 2002 of the world's largest retailers. The strategic alliance led to a fusion of Migros' and LESHOP's online shops. Both Web sites, http://www.migros-shop.ch and http://www.leshop.ch, now give access to the same online supermarket. LESHOP's distribution partner ExpressPost guarantees next day delivery all over Switzerland at a price of CHF12. Migros' infrastructure is combined with LESHOP's proprietary distribution centre. The new shop went online on January 19, 2004, offering a large range of products $(6,000$ items). The very successful launch even forced LESHOP to limit the number of orders per day because capacities were fully used. Customers had to be stopped from placing new orders. Migros and LESHOP jointly promote the new online shop. LESHOP benefits from Migros' strong brand in the traditional retail market [LeSh04].

\section{Explanation of the domains involved}

LESHOP is formerly a pure online grocery retailer with no physical outlets. The online strategy is simply determined by the goal to provide online grocery delivery services to the Swiss. As financial problems arose, an extension of strategy became necessary. New forms of governance and advanced (physical) presence was needed. The cooperation with Migros on the external as well as the internal level makes LESHOP a special case of a marketing potential perspective pursued. Table 5 shows an explanation of the domains involved. 


\begin{tabular}{|l|l|l|l|}
\hline LESHOP & Anchor Domain & \multicolumn{1}{|c|}{ Pivot Domain } & \multicolumn{1}{|c|}{ Impact Domain } \\
\hline $\begin{array}{l}\text { Marketing } \\
\text { Potential }\end{array}$ & Online Strategy & Marketing Strategy & $\begin{array}{l}\text { General Infrastructure } \\
\text { and Processes }\end{array}$ \\
\cline { 2 - 4 } tive & $\begin{array}{l}\text { LESHOP's online strat- } \\
\text { egy emerged in a start- } \\
\text { up setting as stand- } \\
\text { alone strategy. No tra- } \\
\text { ditional/physical mar- } \\
\text { keting strategy coun- } \\
\text { terpart existed. Main } \\
\text { goal is delivering online } \\
\text { grocery ordering possi- } \\
\text { bilities to the Swiss. }\end{array}$ & $\begin{array}{l}\text { LESHOP needed to re- } \\
\text { define and expand its } \\
\text { narrow strategic scope } \\
\text { and competencies. A } \\
\text { more complex market- } \\
\text { ing strategy evolved } \\
\text { which included the co- } \\
\text { operation with Migros. } \\
\text { This lead to e. g. in- } \\
\text { store co-branding, an } \\
\text { extension of the as- } \\
\text { sortment, and higher } \\
\text { visibility. }\end{array}$ & $\begin{array}{l}\text { The general, physical } \\
\text { infrastructure has been } \\
\text { subject to change as } \\
\text { well. Logistics and fa- } \\
\text { cilities are integrated in } \\
\text { the newly created part- } \\
\text { nership. Integration of } \\
\text { marketing operations } \\
\text { and IT-systems should } \\
\text { have taken place. }\end{array}$ \\
\hline
\end{tabular}

Table 5: Marketing Potential Perspective - the Case of LESHOP

\section{Limitations of Research}

Some of the research limitations are based on our sampling approach. We looked for case-based evidence of different approaches in multi channel retailing to show divergent modes of aligning traditional and online channel activities. The four cases suffice to prove the appropriateness of divergent multi channel strategies. However, in order to increase validity, the model of strategic channel alignment should be applied to more cases, also from different industries.

Internal alignment of marketing strategy and online strategy certainly plays a major role in reconstructing and understanding the existence of strategic diversity in multi channel retailing. However, it can be assumed that external factors such as competitor activities or national market structures also impact the development of multi channel strategies. Thus, the model could benefit from a further extension to a model including corporate activities and environmental factors.

The strategic alignment model itself has drawn substantial criticism; in particular as its empirical basis is quite weak and the implications appear to be equivocal. Although work has been done on the operationalization of the model [Luft03a], its high level of abstraction still turns the application into a subjective interpretive task. Ciborra [Cibo97] claims that many cases of successful management seem to show that tinkering, not conscious alignment, lead to successfully aligned domains of management concern. Nevertheless, the alignment model has proven to be a powerful heuristic over time to address issues of coordination, alignment or fit between different domains of strategizing. It pinpoints the need for an integrated, holistic approach. The different alignment perspectives help to identify and de- 
scribe different drivers and approaches in strategy formulation and implementation. However, they cannot be used to derive normative prescriptions, and require expertise to avoid misinterpretation.

\section{Conclusions and Outlook}

In contrast to a stream of literature which assumes or recommends channel integration as the preferable strategy, there is little empirical evidence that comprehensive channel integration is a generally beneficial or widely adopted strategy. On the contrary, our discussion of drivers supports the empirical finding that configuration and appropriateness of a multi channel strategies seem to be dependent on a range of contingency factors.

The model of strategic channel alignment focuses on the general marketing strategy as a major contingency factor for a retailer's online activities. As the application of the model to the four cases has shown, it can be used to reconstruct strategic decisions for multi channel retailing. In contrast to simply proclaiming higher levels of integration as superior multi channel strategies, we have shown that our model is flexible enough to interpret fundamentally different and divergent multi channel strategies as successful and appropriate alignment based on contextdependent contingency factors. While this is one of the main contributions of our approach, we are aware of methodological limitations. Further research is needed in order to widen the empirical base and to identify drivers of converging as well as diverging strategies.

\section{References}

[Ahol04a] Ahold: Company Profile. http://www.ahold.com/aboutahold/companyprofile.asp, 2004, Download 28.01.2004.

[Ahol04b] Ahold: Quarterly sales and trends per region. http://www.ahold.com/uploads/upl_1.pdf, 2004, Download 28.01.2004.

[Bar190] Barley, S. R.: The alignment of technology and structure through roles and networks. Administrative Science Quarterly 35, 1990, pp. 61-103.

[Baue01] Bauer, C.: Strategic Alignment for Electronic Commerce. In: Papp, R. (ed.) Strategic Information Technology: Opportunities for Competitive Advantage. Idea Group, Hershey, 2001, pp. 258-272.

[Bon 03] Bon appétit Group: LeShop.ch, rescued by its own clients! http://www.bon-appetit.ch/?wm=sp $\% 28 \% 2 \mathrm{~d} 1 \% 2 \mathrm{c} 6 \% 2 \mathrm{c} 17 \% 2 \mathrm{c} 86 \% 29 \mathrm{c} \% 28100 \% 29$, 2003, Download 29.01.2004. 
[Cibo97] Ciborra, C. U.: De Profundis? Deconstructing the concept of strategic alignment. Scandinavian Journal of Information Systems 9(1), 1997, pp. 67-82.

[Görs03] Görsch, D.: Multi-channel integration in the retail of physical products: Towards a holistic model of integration elements and consumer perceptions. Samfundslitteratur, Kopenhagen, 2003.

[Hen+96] Henderson, J. C.; Venkatraman, N.; Oldach, S.: Aligning Business and IT Strategies. In: Luftman, J. N. (ed.) Competing in the Information Age: Strategic Alignment in Practice. Oxford University Press, Oxford, 1996, pp. 21-42.

[HeVe93] Henderson, J. C.; Venkatraman, N.: Strategic Alignment: Leveraging information technology for transforming organizations. IBM Systems Journal 32(1), 1993, pp. 4-16.

[LeSh04] LeShop.ch: Corporate Information. http://info.leshop.ch/uk/Welcome.html, 2004, Download 29.01.2004.

[Luft03a] Luftman, J. N.: Assessing Strategic Alignment Maturity. In: Luftman, J. N. (ed.) Competing in the Information Age: Align in the sand. 2 ed. Oxford University Press, Oxford, 2003, pp. 15-48.

[Luft03b] Luftman, J. N.: Competing in the Information Age: Align in the Sand. 2nd ed. Oxford University Press, Oxford, 2003.

[Luft96a] Luftman, J. N.: Applying the Strategic Alignment Model. In: Luftman, J. N. (ed.) Competing in the Information Age: Strategic Alignment in Practice. Oxford University Press, Oxford, 1996, pp. 43-69.

[Luft96b] Luftman, J. N.: Competing in the Information Age: Strategic Alignment in Practice. Oxford University Press, Oxford, 1996.

[Luft96c] Luftman, J. N.: Glossary of Strategic Alignment Terminology. In: Luftman, J. N. (ed.) Competing in the Information Age: Strategic Alignment in Practice. Oxford University Press, Oxford, 1996, pp. 404-411.

[Madd03] Maddali, P.: Tesco in 2003. Global CEO(6), 2003, pp. 65-79.

[McKe03] McKelvey, C.: How Tesco still rules the roost. Precision Marketing 15(36), 2003, pp. 15 .

[Mül+04] Müller-Lankenau, C.; Klein, S.; Wehmeyer, K.: Developing a Framework for Multi Channel Strategies - An Analysis of Cases from the Grocery Retail Industry. In: Tan, Y.-H.; Vogel, D. R.; Gricar, J.; Lenart, G. (eds.) Proceedings of the 17th Bled eCommerce Conference. Moderna organizacija, Kranj, 2004,

[n.a.03] n.a.: 100 Largest Global Retailers. http://www.chainstoreage.com/industry_data/pdfs/global100/2003_globaltop100.pdf, 2003, Download 22.01.2004.

[Naka01] Nakayama, M.: Aligning IT Resources for E-Commerce. In: Papp, R. (ed.) Strategic Information Technology: Opportunities for Competitive Advantage. Idea Group, Hershey, 2001, pp. 185-199. 
[Nels01] Nelson, M. R.: Alignment Through Cross-Functional Integration. In: Papp, R. (ed.) Strategic Information Technology: Opportunities for Competitive Advantage. Idea Group, Hershey, 2001, pp. 40-55.

[OC\&C02] OC\&C: Multichannel Retailing: Der deutsche Einzelhandel steht noch am Anfang.

www.occ-strategy.de/resources/uploads/docs/multichannel.pdf, 2002, Download 23.10. 2002.

[PaLu95] Papp, R.; Luftman, J. N.: Business and IT Strategy Alignment: New Perspectives and Assessments. In: Proceedings of the Proceedings of the AIS Inaugural Americas Conference on Information Systems. Pittsburgh, 1995.

[Papp01a] Papp, R.: Introduction to Strategic Alignment. In: Papp, R. (ed.) Strategic Information Technology: Opportunities for Competitive Advantage. Idea Group, Hershey, 2001, pp. 1-24.

[Papp01b] Papp, R.: Strategic Information Technology: Opportunities for Competitive Advantage. Idea Group Publishing, Hershey, 2001.

[Peap04] Peapod: Corporate Fact Sheet. http://www.peapod.com/corpinfo/peapodFacts.pdf, 2004, Download 28.01.2004.

[RhSh02] Rheault, D.; Sheridan, S.: Reconstruct Your Business around Customers. Journal of Business Strategy 23(2), 2002, pp. 38-42.

[Seyb01] Seybold, P. B.: Get Inside the Lives of Your Customers. Harvard Business Review 79(5), 2001, pp. 80-89.

[Ste+02] Steinfield, C.; Bouwman, H.; Adelaar, T.: The Dynamics of Click-and-Mortar Electronic Commerce: Opportunities and Management Strategies. International Journal of Electronic Commerce 7(1), 2002, pp. 93-119.

[Stei04] Steinfield, C.: The Missing Link: Connecting Physical and Virtual Channels Through Click \& Mortar Electronic Commerce. In: Stanoevska-Slabeva, K. (ed.) The Digital Economy: Anspruch und Wirklichkeit. Springer, Heidelberg, 2004, pp. 141157.

[StK199] Steinfield, C.; Klein, S.: Special Section: Local vs. Global Issues in Electronic Commerce. Electronic Markets 9(1/2), 1999, pp. 45-50.

[Tesc03] Tesco: The Tesco Strategy. http://81.201.142.254/companyInfo/businessStrategy.asp?section=1，2003, Download 13.08.2003. 
